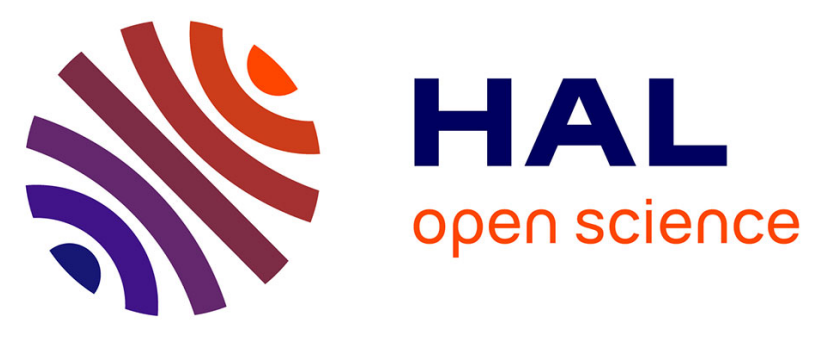

\title{
Understanding the torrefaction of woody and agricultural biomasses through their extracted macromolecular components. Part 1: Experimental thermogravimetric solid mass loss
}

María González Martínez, Capucine Dupont, Denilson da Silva Perez, Gérard Mortha, Sébastien Thiery, Xuan Mi Meyer, Christophe Gourdon

\section{To cite this version:}

María González Martínez, Capucine Dupont, Denilson da Silva Perez, Gérard Mortha, Sébastien Thiery, et al.. Understanding the torrefaction of woody and agricultural biomasses through their extracted macromolecular components. Part 1: Experimental thermogravimetric solid mass loss. Energy, 2020, 205, pp.118067. 10.1016/j.energy.2020.118067 . hal-02917425

\section{HAL Id: hal-02917425 \\ https://imt-mines-albi.hal.science/hal-02917425}

Submitted on 2 Sep 2020

HAL is a multi-disciplinary open access archive for the deposit and dissemination of scientific research documents, whether they are published or not. The documents may come from teaching and research institutions in France or abroad, or from public or private research centers.
L'archive ouverte pluridisciplinaire HAL, est destinée au dépôt et à la diffusion de documents scientifiques de niveau recherche, publiés ou non, émanant des établissements d'enseignement et de recherche français ou étrangers, des laboratoires publics ou privés. 


\title{
Understanding the torrefaction of woody and agricultural biomasses through their extracted macromolecular components. Part 1: Experimental thermogravimetric solid mass loss
}

\author{
María González Martínez a, b, c, *, Capucine Dupont ${ }^{\text {}}$, Denilson da Silva Perez ${ }^{\text {, }}$ \\ Gérard Mortha ${ }^{\mathrm{f}}$, Sébastien Thiéry ${ }^{\mathrm{b}}$, Xuân-mi Meyer ${ }^{\mathrm{c}}$, Christophe Gourdon ${ }^{\mathrm{c}}$ \\ a Université de Toulouse, IMT Mines Albi, RAPSODEE CNRS UMR-5302, Campus Jarlard, F-81013, Albi, Cedex 09, France \\ ${ }^{\mathrm{b}}$ Université Grenoble Alpes, CEA, Laboratory of Bioresources Preparation (LPB), Grenoble, France \\ ${ }^{c}$ Laboratoire de Génie Chimique, Université de Toulouse, CNRS, INPT, UPS, Toulouse, France \\ d IHE Delft Institute for Water Education, Department of Environmental Engineering and Water Technology, Delft, the Netherlands \\ e FCBA, InTechFibres Division, CS 90251, 38044, Grenoble, France \\ ${ }^{\mathrm{f}}$ Laboratoire de Génie des Procédés Papetiers (LGP2), UMR CNRS 5518, Grenoble INP-Pagora, Saint Martin d'Hères, France
}

Keywords:

Biomass

Torrefaction

Solid mass loss

Cellulose

Hemicelluloses

Lignin

\begin{abstract}
A B S T R A C T
The behavior of biomass in torrefaction is determined by that of its macromolecular components, as well as by the biomass type. However, up to now, commercial compounds were typically used for modelling biomass torrefaction. This work proposes to assess the behavior of cellulose, hemicelluloses and lignin in torrefaction through extracted fractions directly isolated from woody and agricultural biomasses (ashwood, beech, miscanthus, pine and wheat straw) thanks to an optimized extraction procedure. The solid kinetics of these extracted fractions were analyzed through thermogravimetric analysis (TGA) in chemical regime conditions $\left(200-300{ }^{\circ} \mathrm{C}\right.$ at $3{ }^{\circ} \mathrm{C} \cdot \mathrm{min}^{-1}$ followed by $30 \mathrm{~min}$ at $\left.300{ }^{\circ} \mathrm{C}\right)$. These experiments highlighted the influence of the biomass type and the sugar composition in the degradation of the polysaccharide fractions in torrefaction, particularly for hemicelluloses. Furthermore, the degree of preservation of the native structure of the macromolecular components, when extracting them from biomass, seems also having an impact their behavior, especially for cellulose. The comparison of the torrefaction solid kinetic profiles of these extracted fractions, dependent on the biomass type, to that of commercial compounds from previous studies suggest that these extracted fractions would be more suitable for biomass torrefaction modelling.
\end{abstract}

Abbreviations: A, ash (from biomass macromolecular composition); ASE Accelerated Solvent Extractor; $C^{\mathrm{I}}$, «cellulose I » extracted fraction; $\mathrm{C}^{\mathrm{II}}$, «cellulose II » extracted fraction; DMSO, dimethyl sulfoxide; DMSOr, «DMSO residue " extracted fraction; $\mathrm{E}$, extractives (from biomass macromolecular composition); EMAL, enzymatic mild acidolysis for lignin extraction; G, guaiacyllignin unit; $\mathrm{H}$, hydroxyphenyl-lignin unit; $\mathrm{H}_{1}$, «hemicelluloses 1 » extracted fraction; $\mathrm{H}_{2}$, «hemicelluloses 2» extracted fraction; L, «lignin » extracted fraction; S-, syringyl-lignin unit; TGA, thermogravimetric analyzer; XRD, X-ray diffraction; wmf, weight-moisture-free basis.

* Corresponding author. Université de Toulouse, IMT Mines Albi, RAPSODEE CNRS UMR-5302, Campus Jarlard, F-81013, Albi, Cedex 09, France.

E-mail address: maria.gonzalez_martinez@mines-albi.fr (M. González Martínez).

\section{Introduction}

The use of renewable energies and, more precisely, of biomass and waste was identified as crucial for the reduction of emissions from the European Union (EU) in the horizon 2030 [1]. Thus, biomass is already the main source of bioenergy in the EU, representing $60 \%$ of the total energy consumption from renewable sources. Forest biomass represented more than $60 \%$ for domestic biomass supplied for energy purposes in 2016, which represents around 80 Mtoe (Megatons of oil equivalent). However, the use of agricultural residues and biowaste significantly increased in the last decade [2]. This context, coupled to the high availability of biomass resources and particularly of biomass waste, requires to improve the knowhow and to optimize biomass transformation technologies. 
Torrefaction is a mild thermal treatment consisting in heating biomass under an inert atmosphere, typically between 200 and $300{ }^{\circ} \mathrm{C}$ and at atmospheric pressure, for a residence time of several tens of minutes to $1 \mathrm{~h} \mathrm{[3]}$. This process is suitable for dry biomass conversion (moisture content below 60\% at harvesting) [4]. Torrefaction products are composed of a torrefied solid (about $70 \%$ in mass) and some gaseous species released (about 30\%) [5,6]. The torrefied solid properties are improved compared to those of raw biomass and tend to be similar to those of coal, including higher carbon content, heating value and hydrophobicity. Gaseous species released include permanent gases, mainly $\mathrm{CO}_{2}$ and $\mathrm{CO}$, and condensable species, mainly water, acids, alcohols, phenols, ketones and furans [7-9]. Temperature is the most influencing operating condition in torrefaction, and thus the yield of torrefied product decreases with it [10-12].

The macromolecular components of biomass, whose proportion and distribution in the raw material depends on the biomass type, strongly influence the transformation through torrefaction $[13,14]$. Previous studies demonstrated that the thermal behavior of the three macromolecular components of biomass was significantly different [15-18]. Cellulose thermal decomposition, which was described through the commercial microcrystalline cellulose, was reported to occur from temperatures close to 300 until $400{ }^{\circ} \mathrm{C}$, the major decomposition happening between 330 and $370{ }^{\circ} \mathrm{C}$ [13]. Hemicellulose degradation starts at low to intermediate torrefaction temperatures $\left(225-250{ }^{\circ} \mathrm{C}\right.$ ) and mostly happens in the torrefaction temperature range, until about $325-350{ }^{\circ} \mathrm{C}[17,19]$. The different behavior of these two sugar-based fractions is thought to be due to differences in crystallinity, presence of amorphous regions, polymerization degree and sugar composition [19-21]. Indeed, while cellulose is a glucose-based polymer [22], hemicelluloses are a combination of hexose (glucose, mannose, galactose) and pentose sugar units (xylose, arabinose) $[23,24]$. On the contrary, lignin is based on a polyaromatic structure, based on phenylpropane units: H- (hydroxyphenyl-), G- (guaiacyl-) and S(syringyl-) units [25]. Lignin typically follows a progressive degradation during torrefaction, from about $200{ }^{\circ} \mathrm{C}[26,27]$ to $250^{\circ} \mathrm{C}$ [28] until high pyrolysis temperatures about $500{ }^{\circ} \mathrm{C}$ [29], $600{ }^{\circ} \mathrm{C}$ [30], $720{ }^{\circ} \mathrm{C}$ [27] or even $900^{\circ} \mathrm{C}$, in function of the heating rate [3]. As a result, lignin is only partially degraded in the torrefaction temperature range.

Extractives and ash are also part of the biomass macromolecular composition. However, their influence in biomass degradation through torrefaction was still not fully elucidated. In the case of extractives, most of the species present lower volatilization temperatures suggesting a probable release below $200{ }^{\circ} \mathrm{C}[31,32]$. The impact of ash on biomass thermal decomposition was clearly identified at pyrolysis [33,34] and gasification temperatures $[35,36]$. In torrefaction, a catalytic effect of potassium on mass loss during torrefaction was suggested [37-40]. However, the representativeness of inorganic elements on the raw biomass on these torrefaction experiments is controversial, as they were based either on an impregnation with commercial compounds or on a modified biomass structure through doping. When comparing raw biomasses of the same nature with a different ash composition, no correlation was clearly identified under torrefaction conditions [41].

Up to know, the behavior of biomass macromolecular components in torrefaction was usually characterized by studying commercial compounds $[8,13,14,17]$. The reason of this approach is the complex structural matrix of biomass [42-44], which makes the extraction of representative fractions of cellulose, hemicelluloses and lignin directly from the raw material a real challenge.

Cellulose is generally extracted from biomass through acid hydrolysis, after a complete lignin removal by a chlorite treatment.
The objective of this treatment is hemicellulose decomposition due to their higher lability compared to cellulose. However, it may also affect cellulose reactivity by degrading cellulose amorphous areas and drastically reducing the degree of polymerization of cellulose chains. A weaker acid treatment may contribute to remove only the amorphous part of the structure, while cellulose crystalline regions with allomorph structure type I from native cellulose, more resistant to hydrolysis, would be preserved [45]. The alkaline solubilization of residual hemicelluloses would be an alternative to the acid hydrolysis [46,47]. The main advantage of this treatment is the preservation of cellulose amorphous regions and of a higher degree of polymerization. However, the high alkali concentration induces changes in the cellulose allomorphic structure due to mercerization (conversion of native cellulose structure type I into a different allomorph, the so-called cellulose II) [48].

A first main part of hemicelluloses in biomass can be extracted through dimethyl sulfoxide (DMSO) $[49,50]$. This treatment is applied to delignified biomass, typically after a chlorite treatment for lignin removal [51]. Its main advantage is the preservation of hemicellulose acetyl groups [50]. A second hemicellulose fraction can be isolated from the residue of the DMSO extraction though a strong alkaline treatment, so as to separate cellulose and residual hemicelluloses. Nevertheless, compared to the first fraction, hemicellulose structure is slightly modified, principally in terms of its acetyl group content, removed by the alkaline treatment [52].

Lignin is generally extracted from biomass through different procedures $[25,53,54]$. Lignin acidolysis using dioxan seems to provide the best compromise between purity and yield. That is the reason why it is one of the most frequently used methods for lignin extraction [55]. Milled wood lignin is obtained through long ball milling followed by purification steps and a dioxan extraction. However, the obtained purity for lignin is moderate and the production yields are low. Enzymatic mild acidolysis for lignin extraction (EMAL) was recently proposed [56]. Even if the yield of production remains low, EMAL allows to obtain lignin of excellent purity. Finally, the Klason procedure was shown to be suitable to quantify lignin in biomass, but not to extract it, as its strong acid treatment has an effect on the condensation degree of the lignin structure [57].

The objective of this study is to assess the contribution of biomass main macromolecular components, namely cellulose, hemicelluloses and lignin, on their solid transformation through torrefaction. To achieve this, an optimized extraction procedure was developed to isolate extracted fractions corresponding to these biomass main macromolecular components, so as to get an improved representativeness of their behavior compared to the classically used commercial compounds. In the first part of this paper, solid degradation profiles of the cellulose, hemicelluloses and lignin fractions in torrefaction were studied versus time and temperature in a thermobalance. In the second part of this paper, a torrefaction kinetic model able to predict biomass solid mass loss in function of its macromolecular composition and biomass type is proposed, based on these experimental results.

\section{Material and methods}

\subsection{EXTRACTION PROCEDURE}

Fractions representing the main biomass macromolecular components were extracted according to a sequence of different methods available in the literature with some in-house adaptations. The acronyms of the extracted fractions are presented in the legend (Fig. 1). Subscripts and Arabic numerals (1 and 2) were used for complementary fractions of the same macromolecular component, as it was the case for hemicelluloses. Superscripts and Roman 


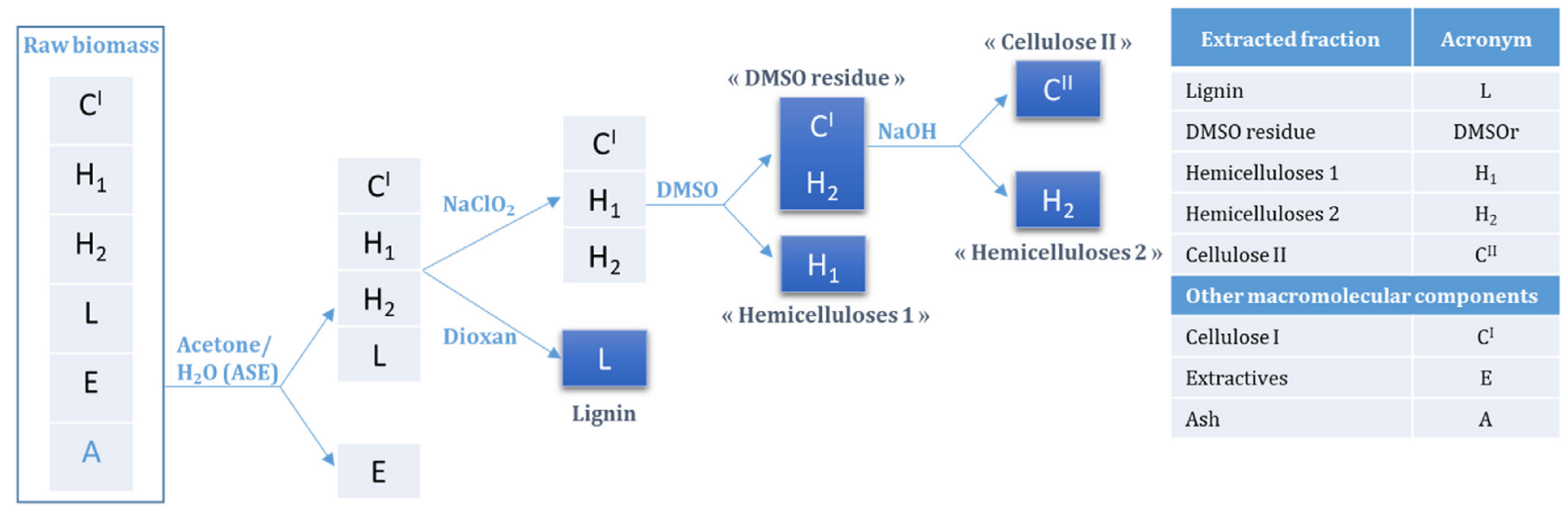

Fig. 1. Extraction procedure of the fractions representing the main biomass macromolecular components and extracted fractions obtained from raw biomass.

numerals (I and II) were indicated for different allomorphs of the same macromolecular component, namely cellulose.

Biomass, both wood chips, agricultural straw and grass, were firstly ground using a laboratory 5-knife mill (Pulverisette) equipped with $1 \mathrm{~mm}$ sieve.

First of all, extractives were removed using an ASE (Accelerated Solvent Extractor) with 2 cycles at 1500 psi, firstly with water at $110{ }^{\circ} \mathrm{C}$ then with acetone at $95{ }^{\circ} \mathrm{C}$ equipped with 12 independent $200 \mathrm{~mL}$ extraction cartridges with an automatic autosampler [58]. The extraction cells were filled up with a mixture of biomass powder (size particle below $1 \mathrm{~mm}$ ) and glass beads. The extracted material was air-dried during one week before lignin or polysaccharides extraction.

Lignin fraction (L) was extracted by refluxing the extractivesfree biomass powder in a dioxan/water $(85 / 15 \mathrm{v} / \mathrm{v})$ mixture containing $0.01 \mathrm{M} \mathrm{HCl}$ for $4 \mathrm{~h}$ under nitrogen [55]. The solubilized lignin was filtered out and precipitated by evaporating half of the volume of the solution using a rotative evaporator under vacuum. Water was added and the previous steps were repeated five times to allow a complete removal of dioxan. The precipitated lignin was then centrifuged, washed with water to neutrality, and finally freeze-dried.

The acidic medium used in lignin extraction could partially hydrolyze cellulose and hemicelluloses. Therefore, polysaccharide fractions were isolated from a new sample of extractives-free biomasses. Before separating polysaccharides, it was necessary to perform a complete delignification of the sample. Wood powder was first delignified using sodium chlorite in an acetate/acid buffer $(\mathrm{pH}=4.6)$ in a $5 \mathrm{~L}$ glass reactor (liquor/biomass weight ratio $=6)$, at $60{ }^{\circ} \mathrm{C}$, under mechanical stirring and nitrogen gas flow [59]. Sodium chlorite was progressively added to the medium until complete delignification. The measurement of Kappa number (carried out using the ISO 302-2015 standard method) of the treated biomass samples was used to follow delignification. Extraction time varied between one and two weeks depending on the lignin content and raw materials. At the end of the delignification, biomass particles were totally converted into fibers, which were thoroughly washed with demineralized water until neutral $\mathrm{pH}$.

Two fractions of hemicelluloses were obtained by combining two successive treatments, an extraction through dimethyl sulfoxide (DMSO) and an alkaline hydrolysis.

The first fraction, called here « hemicelluloses $1 »\left(\mathrm{H}_{1}\right)$, was obtained by a mild treatment based on an extraction with DMSO in a $5 \mathrm{~L}$ glass reactor (liquor/wood weight ratio $=6$ ), at room temperature, under mechanical stirring and nitrogen gas flow. After the extraction, the liquid phase was separated by filtering over Buchner filter (porosity 2), and the solid fraction, called here « DMSO residue» (DMSOr), thoroughly washed with deionized water. Because of the high boiling point of DMSO, it was not possible to remove it by evaporation under vacuum. $\mathrm{H}_{1}$ fraction was then obtained by dialyzing the DMSO of the solution. The liquid phase was distributed in 20 small bags of cellophane membranes (cut-off MW 3600) which were placed in a large volume of distilled water $(20 \mathrm{~L})$. The dialysis took place during two weeks and water was changed twice a day. Hemicelluloses were then recovered by freeze-drying and lyophilization.

The second fraction, called here « hemicelluloses 2 » $\left(\mathrm{H}_{2}\right)$ was obtained by treating DMSOr fraction in alkaline conditions $\mathrm{NaOH}$, $2.5 \mathrm{M}, 60{ }^{\circ} \mathrm{C}, 30 \mathrm{~min}$, liquor/biomass weight ratio = 6). After the extraction, the liquid phase was separated by filtering over Buchner filter (porosity 2). $\mathrm{H}_{2}$ fraction was also obtained through dialysis as described above but in this case the dialysis was carried out until the conductivity of the water bath remained unchanged for $24 \mathrm{~h}$, indicating that all the $\mathrm{NaOH}$ was completely removed. Hemicelluloses were also recovered by freeze-drying and lyophilization.

The solid fraction obtained after the alkaline treatment was neutralized with diluted $\mathrm{HCl}$, dialyzed with membranes and lyophilized. This fraction, called « cellulose II» $\left(C^{\mathrm{II}}\right)$, contains essentially cellulose from the allomorphic type II.

As $\mathrm{H}_{1}$ and $\mathrm{H}_{2}$ are sensible to heat, these fractions were lyophilized so as to remove water without heating, while $C^{\text {II }}$ were directly air-dried. In the case of DMSOr, a part of it was lyophilized for the XDR crystallinity tests while a second part was dried at $105^{\circ} \mathrm{C}$ for $24 \mathrm{~h}$ for torrefaction experiments. Lyophilization allowed to obtain polysaccharide fractions under the shape of a cotton-like material, which simplified their handling in torrefaction experiments. L fraction was dried at room temperature for several days and ground manually.

\subsection{CARBOHYDRATE COMPOSITION}

The carbohydrate composition was determined after a second acidic post-hydrolysis of the liquor to depolymerize all remaining oligomers to monosaccharides using diluted $\mathrm{H}_{2} \mathrm{SO}_{4}$ aqueous solution (2\%) for $1 \mathrm{~h}$ at $121^{\circ} \mathrm{C}$ in an autoclave [63]. Monosugar content was determined from ionic liquid chromatography after acidic hydrolysis of the polysaccharides. Monosugar analysis was carried out after a two-step acidic hydrolysis of wood and pulps, by the ASTM method E1758 - 01 (2007). Quantification of neutral monosugars was obtained on a DIONEX HPAE-PAD ion chromatograph equipped 
with a pulsed amperometric detector.

\subsection{XRD CHARACTERIZATION}

X-Ray diffraction (XRD) characterization was carried out for $\mathrm{C}^{\mathrm{II}}$ and DMSOr fractions for investigating possible changes in cellulose structure. For this purpose, an XPERT-PRO MPD Diffractometer system was used, with the measuring program from PANalytical. The anode material was copper, with a selected wavelength $\mathrm{K} \alpha$ $(\mathrm{Cu})=1.5419 \AA$ A. The reflection method was Bragg Brentano type.

\subsection{THERMOGRAVIMETRIC ANALYSIS}

Remaining solid mass of the extracted fractions through torrefaction was followed in function of time and temperature in a thermogravimetric analyzer (TGA). A three-plate crucible $(10 \mathrm{~mm}$ diameter) allowed to use a higher mass than in typical torrefaction experiments [60]. Its suspended position in the TGA oven, as well as the maximum bed thickness of sample per plate $(2 \mathrm{~mm})$, were set so as to ensure chemical regime conditions for the three sample layers [61]. About $100 \mathrm{mg}$ of sample were used for experiments involving $\mathrm{L}, \mathrm{C}^{\mathrm{II}}$ and DMSOr fractions. The low density of the hemicellulose fractions limited their mass to $50 \mathrm{mg}$ for $\mathrm{H}_{1}$ and to $25 \mathrm{mg}$ for $\mathrm{H}_{2}$.

Samples were torrefied in the thermobalance under a $50 \mathrm{~mL} /$ min helium (He) flow. The heating program started by a sample pre-heating from room temperature to around $70{ }^{\circ} \mathrm{C}$ at a heating rate of $3{ }^{\circ} \mathrm{C} \cdot \mathrm{min}^{-1}$. At this point, the stabilization was achieved between the internal heating of the oven and the cooling water temperature. Then, a second pre-heating stage was carried out until $200{ }^{\circ} \mathrm{C}$, at $3{ }^{\circ} \mathrm{C} \cdot \mathrm{min}^{-1}$, which was considered as the reference temperature for the beginning of torrefaction. At $200{ }^{\circ} \mathrm{C}$, the moisture content can be considered as negligible as reactions associated to torrefaction have not started yet. From room temperature to $200{ }^{\circ} \mathrm{C}$, mass loss was neglected (typically below 3\%) [62]. Torrefaction experiments were then carried out by heating the sample from 200 to $300{ }^{\circ} \mathrm{C}$ at $3^{\circ} \mathrm{C} \cdot \mathrm{min}^{-1}$, and then by keeping it at $300{ }^{\circ} \mathrm{C}$ for $30 \mathrm{~min}$.

The repeatability of torrefaction experiments was checked by carrying out each experiment twice. The standard deviation in mass loss calculations was below $0.5 \%$. The results of the thermogravimetric analysis are expressed in weight-moisture-free basis (wmf).

\section{Results and discussion}

\subsection{CHARACTERIZATIONS OF THE EXTRACTED FRACTIONS}

\subsubsection{Composition of the polysaccharide-based fractions}

Polysaccharide based-fractions were characterized in terms of sugar composition and acetyl group content (Table 1) as defined in Ref. $[41,58,63]$. Sugar composition of the raw biomasses was also added to Table 1 for comparison [41].

Xylose composition was quite similar for the two hemicellulose fractions, except for pine fractions, for which xylose is principally present in $\mathrm{H}_{2}$ fractions (Table 1). Mannose was mostly found in wheat straw and miscanthus $\mathrm{H}_{2}$ fractions. However, in the case of pine, most of the galactose was found in $\mathrm{H}_{1}$ fraction, together with mannose, as they are associated in galactomannan and galactoglucomannan sugars in coniferous wood [51]. This might suggest a different stability of the mannose-based sugars in function of the biomass type. Acetyls were mostly present in $\mathrm{H}_{1}$ fractions, as

Table 1

Neutral monosugar distribution and functional groups of the polysaccharide fractions.

\begin{tabular}{|c|c|c|c|c|c|c|}
\hline \multirow{3}{*}{ Extracted fractions } & \multicolumn{5}{|c|}{ Neutral sugars balance (normalized) } & \multirow{3}{*}{$\begin{array}{l}\text { Functional groups } \\
\text { Acetyl groups } \\
\% \text { wmf** }\end{array}$} \\
\hline & \multirow{2}{*}{$\frac{\text { Glucose }}{\% *}$} & \multirow[t]{2}{*}{ Xylose } & \multirow[t]{2}{*}{ Mannose } & \multirow[t]{2}{*}{ Galactose } & \multirow[t]{2}{*}{ Arabinose } & \\
\hline & & & & & & \\
\hline \multicolumn{7}{|c|}{ «Hemicelluloses 1» $\left(\mathrm{H}_{1}\right)$} \\
\hline Ash-wood & 5.5 & 72.4 & 0.0 & 0.3 & 0.6 & 21.2 \\
\hline Beech & 0.2 & 75.9 & 0.0 & 0.4 & 0.6 & 22.9 \\
\hline Miscanthus & 12.5 & 64.4 & 0.0 & 0.7 & 5.9 & 16.5 \\
\hline Pine & 14.8 & 18.4 & 49.2 & 4.1 & 3.0 & 10.5 \\
\hline Wheat straw & 32.3 & 52.0 & 0.0 & 1.6 & 4.9 & 9.1 \\
\hline \multicolumn{7}{|c|}{ «DMSO residue» (DMSOr) } \\
\hline Ash-wood & 77.3 & 14.9 & 1.8 & 0.0 & 0.8 & 5.2 \\
\hline Beech & 78.3 & 16.2 & 0.0 & 0.0 & 0.4 & 5.0 \\
\hline Miscanthus & 76.6 & 11.9 & 5.9 & 0.2 & 0.3 & 5.2 \\
\hline Pine & 78.7 & 16.2 & 0.0 & 0.0 & 1.2 & 4.0 \\
\hline Wheat straw & 78.5 & 5.4 & 11.5 & 0.2 & 0.5 & 3.8 \\
\hline \multicolumn{7}{|c|}{ «Hemicelluloses 2» $\left(\mathrm{H}_{2}\right)$} \\
\hline Ash-wood & 16.7 & 75.8 & 0.0 & 0.8 & 5.8 & 0.9 \\
\hline Beech & 12.3 & 79.9 & 0.0 & 0.8 & 6.2 & 0.8 \\
\hline Miscanthus & 9.8 & 86.4 & 2.0 & 0.6 & 0.6 & 0.7 \\
\hline Pine & 6.2 & 80.2 & 7.5 & 0.7 & 4.2 & 1.2 \\
\hline Wheat straw & 9.9 & 46.6 & 33.3 & 3.1 & 6.4 & 0.8 \\
\hline \multicolumn{7}{|l|}{ «Cellulose II» $\left(C^{\mathrm{II}}\right)$} \\
\hline Ash-wood & 98.2 & 0.0 & 1.8 & 0.0 & 0.0 & n.m. \\
\hline Beech & 100.0 & 0.0 & 0.0 & 0.0 & 0.0 & n.m. \\
\hline Miscanthus & 100.0 & 0.0 & 0.0 & 0.0 & 0.0 & n.m. \\
\hline Pine & 99.1 & 0.0 & 0.9 & 0.0 & 0.0 & n.m. \\
\hline Wheat straw & 100.0 & 0.0 & 0.0 & 0.0 & 0.0 & n.m. \\
\hline \multicolumn{7}{|l|}{ Raw biomasses [41] } \\
\hline Ash-wood & 69.2 & 24.9 & 2.0 & 1.1 & 2.7 & 3.6 \\
\hline Beech & 63.9 & 29.1 & 3.0 & 2.0 & 2.0 & 8.3 \\
\hline Miscanthus & 69.9 & 26.1 & 0.5 & 0.7 & 2.9 & 2.6 \\
\hline Pine & 70.6 & 8.2 & 16.9 & 2.8 & 1.6 & 1.7 \\
\hline Wheat straw & 63.7 & 29.7 & 0.8 & 1.6 & 4.2 & 1.7 \\
\hline
\end{tabular}

$* \%$ of the total monosugars; $* * \% \mathrm{wmf}=$ weight-moisture-free; n.m.: not measured. 
the alkaline treatment to obtain the second fractions destroys the acetate functional group in hemicelluloses. These differences in composition indicated that both hemicellulose fractions are independent.

DMSOr fractions were mainly constituted of cellulose, as it was mainly composed of glucose (Table 1). However, hemicellulose sugars and acetyl groups were also present in considerable amounts. The similar glucose to xylose ratios in DMSOr fractions were close for all the extracted fractions, which indicated a similar proportion of cellulose and hemicelluloses in these fractions. All DMSOr fractions, except that from wheat straw, presented higher xylose content compared to mannose content. This is also de the case for all raw biomasses, except pine. As a result, a higher recovery of mannose was achieved in the $\mathrm{H}_{1}$ fraction for all biomasses except for wheat straw.

Sugar distribution of the $\mathrm{C}^{\mathrm{Il}}$ fractions proved their high purity, as they were principally constituted of glucose and only minor amounts of mannose for ash-wood and pine celluloses (Table 1). Commercial microcrystalline cellulose, i.e. Avicel, has typically a glucose content of $96.1 \% \mathrm{wmf}$, a xylose content of $2.4 \% \mathrm{wmf}$ and a mannose content of $1.5 \% \mathrm{wmf}$ [64], which represents a lower purity compared to $\mathrm{Cl}^{\mathrm{II}}$ fractions.

\subsubsection{Cellulose allomorphs}

The final alkaline treatment to the DMSO residue in the extraction procedure lead to a high purity in glucose for the $C^{\text {Il }}$ fractions. However, the operating conditions used in this step were suspected to induce mercerization. The mercerization in alkaline medium is due to $\mathrm{Na}^{+}$ions going into the cellulose structure and separating glucan chains. Then, these chains recrystallize in an antiparallel structure with higher stability, named « cellulose II» [65], which differs from native cellulose in biomass, called « cellulose I» and formed by parallel glucan chains. X-Ray diffraction (XRD) characterization was then carried out on $\mathrm{C}^{\mathrm{II}}$ and DMSOr fractions for investigating possible changes in cellulose structure (Fig. 2).

XRD results confirmed cellulose mercerization, this is, a conversion of cellulose allomorphic structure type I (Fig. 2, left) in all DMSOr fractions to cellulose II in all $\mathrm{C}^{\mathrm{II}}$ fractions (Fig. 2, right). That is the reason why the final solid residue was called $C^{\mathrm{II}}$ in this work. During the whole extraction procedure, cellulose I was preserved in all steps before the alkaline extraction (until the DMSOr fractions). As a result, DMSOr fractions was also analyzed in terms of characterization and behavior in torrefaction. Therefore, by comparing the behavior in torrefaction of DMSOr and $C^{\mathrm{II}}$ fractions, the influence of cellulose allomorphic structure on its conversion in torrefaction could be assessed. Furthermore, the influence of the presence of hemicellulose sugars on a cellulose fraction could also be evaluated by comparing the behavior in torrefaction of $\mathrm{H}_{1}$ and $\mathrm{H}_{2}$ fractions to that of DMSOr fraction.

\subsection{TORREFACTION EXPERIMENTS}

\subsubsection{Cellulose fractions}

Both CII and DMSOr fractions were studied due to their different cellulose allomorphs (Fig. 2). Furthermore, the study of DMSOr fractions allowed to assess the influence of the presence of hemicellulose sugars in a cellulose fraction.

3.2.1.1. «Cellulose II » fraction $\left(C^{I I}\right)$. The remaining solid mass profiles were generally similar for all « cellulose II » fractions $\left(\mathrm{C}^{\mathrm{II}}\right)$ for all biomass types (Fig. 3, left). The final remaining solid mass at the end of the non-isothermal torrefaction was similar for all samples, varying from 92.2 to $86.6 \% \mathrm{wmf}$. Then, the final remaining solid mass for $\mathrm{C}^{\mathrm{II}}$ fractions ranged between 66.0 and $55.8 \% \mathrm{wmf}$ at the end of the isothermal torrefaction at $300{ }^{\circ} \mathrm{C}$

Degradation rate curves (Fig. 3 , right) showed similar profiles for ash-wood and wheat straw $\mathrm{C}^{\mathrm{II}}$ fractions on the one hand, and for beech and pine $\mathrm{C}^{\mathrm{II}}$ fractions on the other hand. The acceleration in the degradation of these fractions was progressive from low torrefaction temperatures $\left(230{ }^{\circ} \mathrm{C}\right)$. In the isothermal step, the degradation rate of $\mathrm{C}^{\mathrm{II}}$ samples started at around $1.0 \% \mathrm{wmf} \cdot \mathrm{min}^{-1}$ for pine and $1.4 \% \mathrm{wmf} \cdot \mathrm{min}^{-1}$ for ash-wood $\mathrm{C}^{\mathrm{II}}$. Degradation rates were rather constant versus time for pine and beech fractions, while they decreased progressively with time for the other fractions. The degradation rate at the end of the experiment was in the same order of magnitude for all samples (around $1.0 \% \mathrm{wmf} \cdot \mathrm{min}^{-1}$ ).

The degradation of $\mathrm{C}^{\mathrm{II}}$ fractions was observed from temperatures (around $230{ }^{\circ} \mathrm{C}$ ) lower than those reported previously for commercial microcrystalline celluloses such as Avicel [17,26,27,66]. However, the reported degradation rate at $300{ }^{\circ} \mathrm{C}$ was much lower for commercial cellulose compared to $\mathrm{C}^{\mathrm{II}}$ fractions [14]. This result might be due to the higher thermochemical reactivity of commercial Avicel, due to the acid hydrolysis employed for its extraction, typically carried out on a bleached sulfite pulp [66]. The milder operating conditions of the extraction procedure selected in this study would less impact cellulose reactivity, by contributing in the preservation of cellulose from native biomass. As a result, a higher degree of polymerization might be expected, as well as the preservation of the amorphous areas from native cellulose, which is not the case with the commercial acid hydrolysis. Furthermore, a higher purity in glucose was achieved for cellulose extracted fractions (Table 1), compared to reported values for commercial
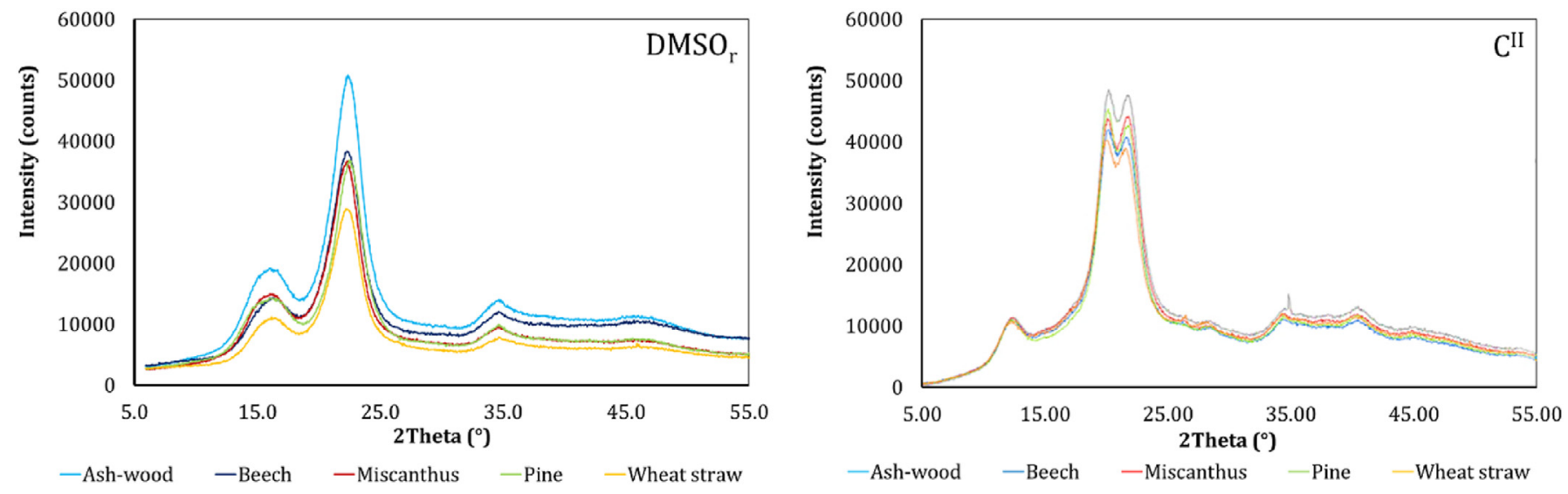

Fig. 2. XRD spectra of DMSOr (left) and $\mathrm{Cl}^{\mathrm{II}}$ (right) extracted fractions from the 5 biomasses. 

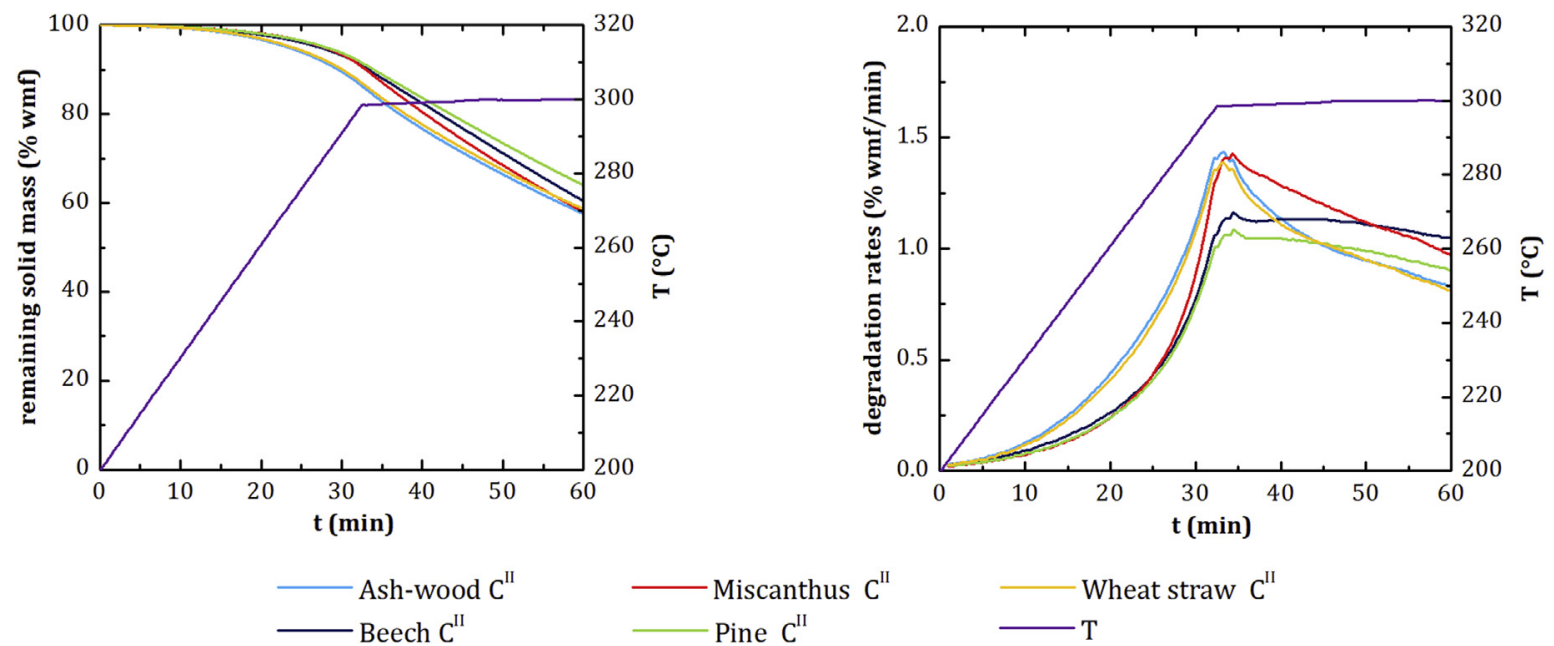

Fig. 3. Remaining solid mass (left) and degradation rates (right) versus time and temperature in torrefaction in TGA-GC/MS for the $\mathrm{C}^{\mathrm{II}}$ fractions from the biomasses of study.

microcrystalline cellulose, which might also impact its reactivity.

3.2.1.2. «DMSO residue » fraction (DMSOr). «DMSO residue» (DMSOr) fractions degradation profiles and extent were shown to be dependent on the biomass type (Fig. 4). The final remaining solid mass at the end of the isothermal step was between $42.1 \% \mathrm{wmf}$ for ash-wood DMSOr and $64.1 \%$ wmf for pine DMSOr (Fig. 4, left). Degradation rates were below $1.9 \% \mathrm{wmf} \cdot \mathrm{min}^{-1}$ for all DMSOr fractions (Fig. 4, right). Degradation rate profiles presented a similar shape to those of the equivalent $C^{\mathrm{II}}$ fractions. However, the degradation extent of this fraction in torrefaction was higher, compared to that of $\mathrm{C}^{\mathrm{II}}$ fractions, presumably because of the presence of hemicellulose sugars (Table 1 ).

Three main solid degradation profiles could be distinguished for DMSOr fractions through the degradation rate profiles (Fig. 4, right). First of all, ash-wood DMSOr presented a degradation rate profile characterized by a global and soft mass loss acceleration. This kind of profile was also observed for beech, whose deceleration phase was shorter, from around 265 to $275{ }^{\circ} \mathrm{C}$. The second kinetic profile corresponded to miscanthus DMSOr, whose behavior was close to that of deciduous wood, with a clear distinction between acceleration and deceleration steps and without the last acceleration step before $300{ }^{\circ} \mathrm{C}$. Finally, pine DMSOr presented a different solid kinetic behavior, which consisted in an acceleration of the mass loss until the end of the non-isothermal torrefaction. The degradation profile of wheat straw DMSOr was intermediate between the two previous types. It presented a slight change in the mass loss acceleration around $285^{\circ} \mathrm{C}$, which might be due to the higher mannose content, less reactive than xylose, compared to the other DMSOr fractions.

In the isothermal step, degradation rate profiles could be classified in the same groups. It is noteworthy that the final remaining solid mass tends to stabilize around $0.7-0.8 \% \mathrm{wmf} \cdot \mathrm{min}^{-1}$ whatever the biomass was, while their degradation rate values at the beginning of this step were relatively different $(1.2-1.7 \%$ $\mathrm{wmf} \cdot \mathrm{min}^{-1}$ ). This result might indicate that solid mass loss below $300{ }^{\circ} \mathrm{C}$ could principally correspond to that of hemicellulose sugars, due to the differences in the xylose and mannose composition of the samples. However, the degradation in the isothermal step would rather only correspond to that of glucose, whose content is similar for all DMSOr fractions. Indeed, degradation rate profiles at $300{ }^{\circ} \mathrm{C}$ for DMSOr (Fig. 4) and for $\mathrm{Cl}^{\mathrm{II}}$ (Fig. 3) fractions were similar. This might indicate that the change in cellulose allomorphic structure due to the extraction procedure did not significantly impact cellulose solid kinetics in torrefaction.

To sum up, the presence of hemicelluloses in the DMSOr fraction
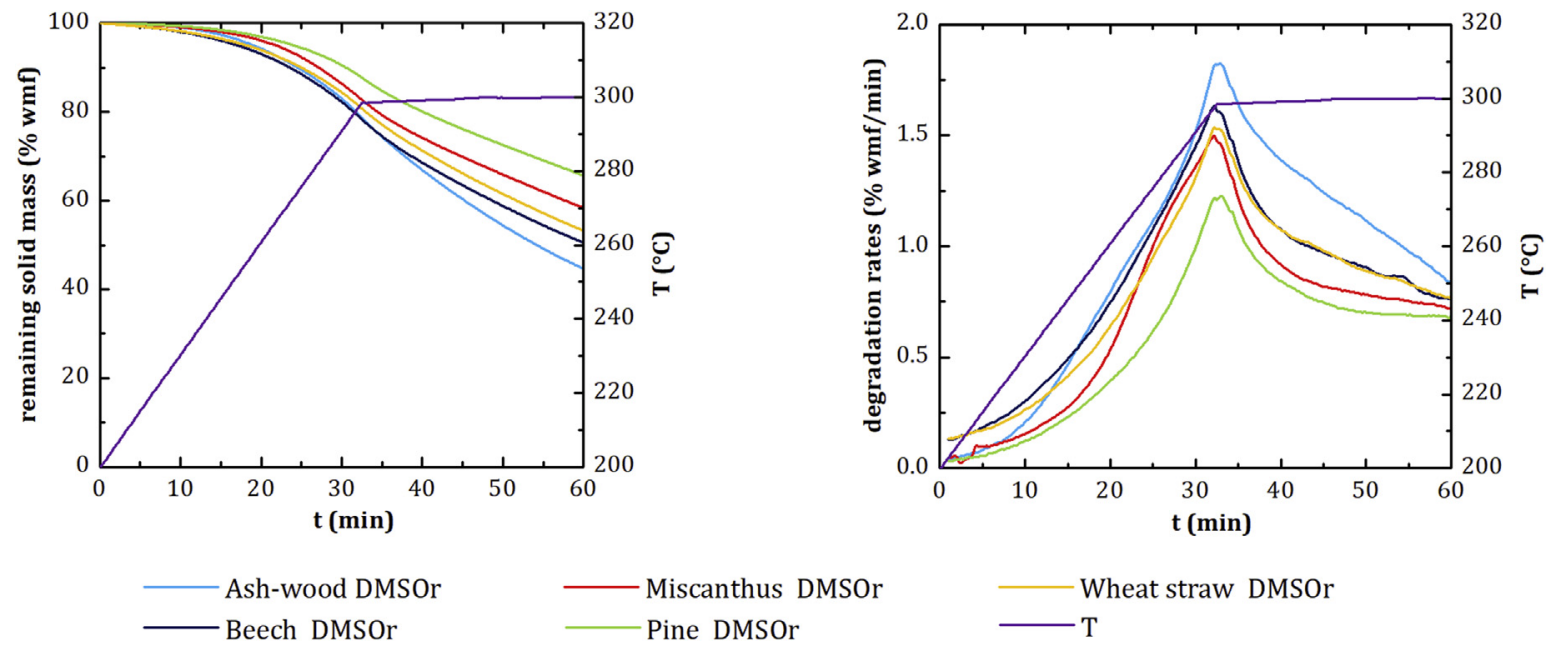

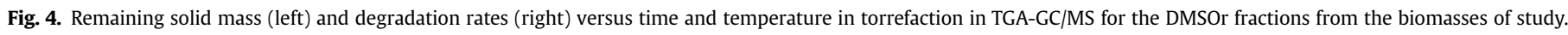



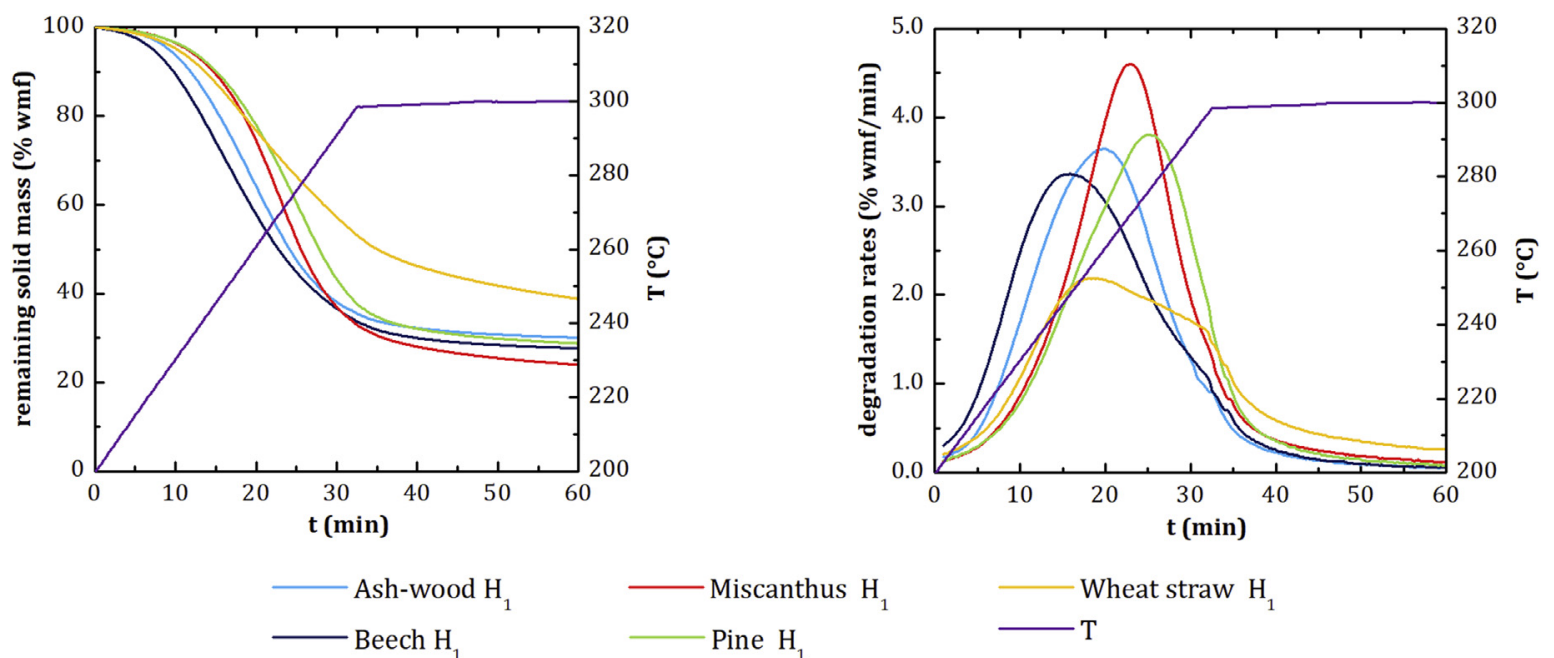

Fig. 5. Remaining solid mass (left) and degradation rates (right) versus time and temperature in torrefaction in TGA-GC/MS for the $\mathrm{H}_{1}$ fractions from the biomasses of study.

leads to a more enhanced solid mass loss, especially below $300{ }^{\circ} \mathrm{C}$. The change in cellulose allomorphic structure does not seem to significantly impact its degradation in torrefaction.

\subsubsection{Hemicellulose fractions}

3.2.2.1. «Hemicelluloses 1 » fraction $\left(H_{1}\right)$. The remaining mass loss at the end of the non-isothermal torrefaction was relatively close for all « hemicelluloses 1 » fractions $\left(\mathrm{H}_{1}\right)$, between 32.0 and $36.7 \% \mathrm{wmf}$, except for wheat straw (52.1\%wmf, Fig. 5, left). This value moved to around $38.3 \% \mathrm{wmf}$ for wheat straw $\mathrm{H}_{1}$ fraction and 23.7 \%wmf for miscanthus $\mathrm{H}_{1}$ fraction at the end of the isothermal torrefaction step. These results are in agreement with previous studies pointing out the high extent of hemicelluloses degradation through torrefaction $[8,17,18,67]$. Maximum degradation rates were between $2.0 \% \mathrm{wmf} \cdot \mathrm{min}^{-1}$ for wheat straw $\mathrm{H}_{1}$ fraction and $4.7 \% \mathrm{wmf} \cdot \mathrm{min}^{-1}$ for miscanthus $\mathrm{H}_{1}$ fraction (Fig. 5, right).

Solid degradation profiles were to be similar for all $\mathrm{H}_{1}$ samples, except for wheat straw $\mathrm{H}_{1}$ fraction (Fig. 5, right). It is noteworthy that the maximum degradation rate was not reached at the same temperature for all $\mathrm{H}_{1}$ fractions (Fig. 5, left).

Similarities in solid kinetics during the non-isothermal torrefaction step allowed to classify $\mathrm{H}_{1}$ fractions in three groups. First of all, similarities were found in the behavior of $\mathrm{H}_{1}$ fractions from deciduous wood (from ash-wood and beech), which may be derived from their similar composition in xylose (around 75\% wmf) and acetyl groups (around 22\% wmf). Ash-wood and beech $\mathrm{H}_{1}$ fractions were characterized by a regular acceleration of the solid mass loss from about $210{ }^{\circ} \mathrm{C}$. This acceleration seemed to start a little later for ash-wood $\mathrm{H}_{1}$ fraction, compared to the corresponding fraction from beech. The maximum degradation rate was achieved at $245{ }^{\circ} \mathrm{C}$ for beech and slightly later for ash-wood $\mathrm{H}_{1}$ fraction, around $260^{\circ} \mathrm{C}$.

Miscanthus $\mathrm{H}_{1}$ fraction presented a very close behavior to that of the previous $\mathrm{H}_{1}$ fractions. However, the acceleration of the solid mass loss occurred at slightly higher temperatures (around $220^{\circ} \mathrm{C}$ ). Furthermore, it showed a steeper slope until the highest degradation rates, which were reached at around $270{ }^{\circ} \mathrm{C}$. These differences with deciduous wood might be explained by the higher glucose content ( $12.5 \% \mathrm{wmf}$ ) of the miscanthus $\mathrm{H}_{1}$ fraction, in detriment to a reduction in the xylose (64.4\%wmf) and acetyl group (16.5\%) content.

Pine $\mathrm{H}_{1}$ degradation rate profile was intermediate to those of the previous $\mathrm{H}_{1}$ fractions. It showed a maximum degradation rate around $280{ }^{\circ} \mathrm{C}$, which is comparable to the behavior of deciduous wood $\mathrm{H}_{1}$ fractions. However, a slight deceleration could be appreciated around $250{ }^{\circ} \mathrm{C}$, inducing a small change in the degradation rate profile. Pine $\mathrm{H}_{1}$ sugar composition mainly consists of mannose (49.2\%wmf) and lower amounts of xylose (18.4\% wmf) and glucose (14.8\%wmf). This composition could explain that the maximum in the degradation pine $\mathrm{H}_{1}$ is reached at higher temperatures, as mannose-based sugars were pointed out in the literature as less reactive than xylose-based ones [29].

Finally, the kinetic behavior of wheat straw $\mathrm{H}_{1}$ was close to that of the other fractions until $250^{\circ} \mathrm{C}$, but with a slower acceleration. From this temperature, solid mass loss was significantly decelerated until $300{ }^{\circ} \mathrm{C}$, by losing around $0.7 \% \mathrm{wmf} \cdot \mathrm{min}^{-1}$ in this period. The behavior of this fraction was checked as reproducible and could be justified by its high glucose content compared to the xylose content (Table 1). This might suggest that a high glucose content, rather typical of a cellulose-based fraction, would be susceptible to mitigate the degradation of a given hemicellulose fraction.

3.2.2.2. «Hemicelluloses 2» fraction $\left(\mathrm{H}_{2}\right)$. The final remaining mass loss, after the non-isothermal torrefaction step, was close for all the «hemicelluloses 2» fractions $\left(\mathrm{H}_{2}\right)$, between 24.9 \%wmf for miscanthus $\mathrm{H}_{2}$ fraction and 33.3 \%wmf for wheat straw $\mathrm{H}_{2}$ fraction (Fig. 6, left). Degradation rates were in the same order of magnitude as those of the corresponding $\mathrm{H}_{1}$ fractions. They increased to around $3.1 \% \mathrm{wmf} \cdot \mathrm{min}^{-1}$ for ash-wood and pine $\mathrm{H}_{2}$ fractions and to $4.7 \% \mathrm{wmf} \cdot \mathrm{min}^{-1}$ miscanthus $\mathrm{H}_{2}$ fraction. In the end of the isothermal step, degradation rates decreased drastically, until values below $0.1 \% \mathrm{wmf} \cdot \mathrm{min}^{-1}$ at the end of this period (Fig. 6, right). By comparing both hemicellulose fractions per biomass, it was shown that extracted $\mathrm{H}_{1}$ (Fig. 5) and $\mathrm{H}_{2}$ fractions (Fig. 6) present a different behavior.

Regarding the remaining solid mass loss profiles (Fig. 6, left), ash-wood and pine $\mathrm{H}_{2}$ fractions presented a slightly higher mass loss below $300{ }^{\circ} \mathrm{C}$, while the degradation of wheat straw $\mathrm{H}_{2}$ fraction was the lowest. This behavior might be due to the higher mannose content of this last fraction (33.3\%, Table 1), while the other $\mathrm{H}_{2}$ fractions were principally composed of xylose [29]. However, the low mannose content of pine (7.5\%) and miscanthus (2\%) $\mathrm{H}_{2}$ fractions did not seem to impact their behavior in torrefaction, at least below $300{ }^{\circ} \mathrm{C}$, as they presented different degradation profiles. All 

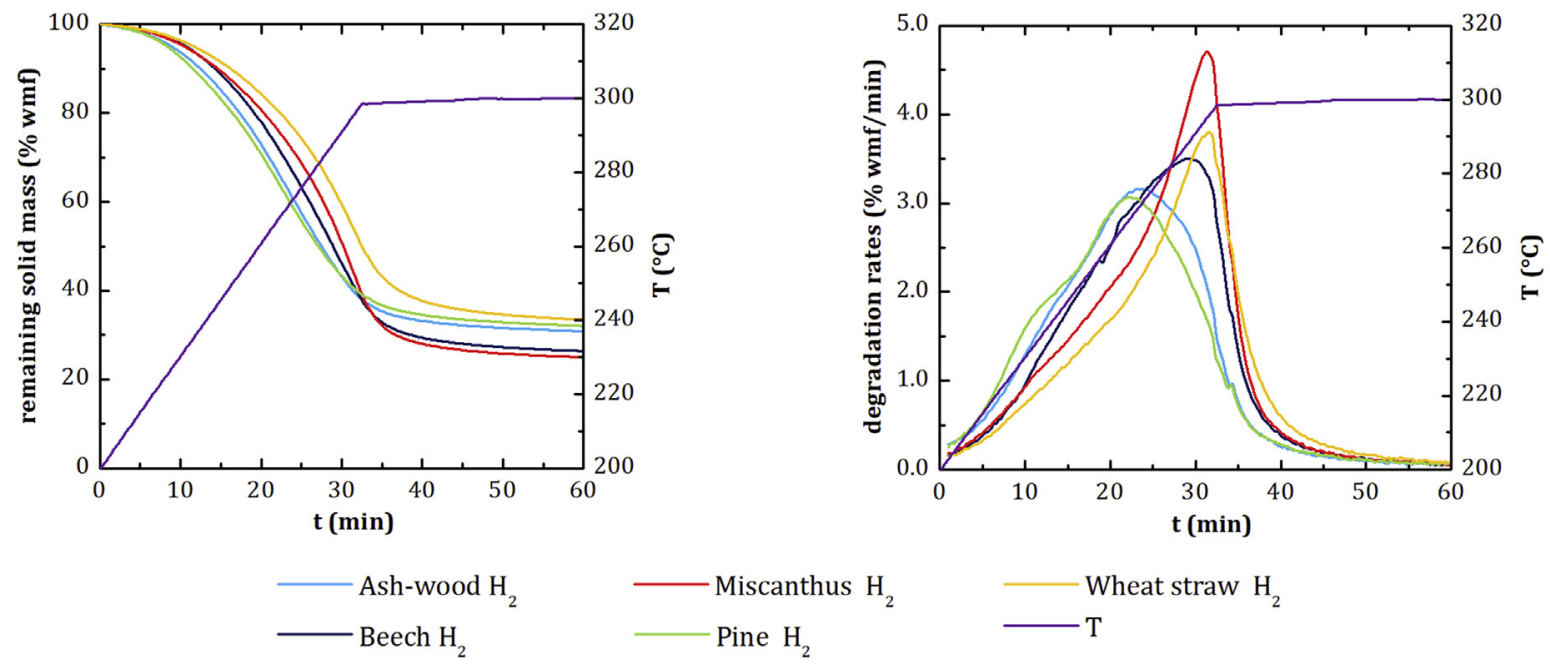

Fig. 6. Remaining solid mass (left) and degradation rates (right) versus time and temperature in torrefaction in TGA-GC/MS for the $\mathrm{H}_{2}$ fractions from the biomasses of study.

$\mathrm{H}_{2}$ fractions presented a low glucose content (6.2-16.7\%), which might contribute to the stabilization of solid mass loss at $300{ }^{\circ} \mathrm{C}$ (Fig. 6).

A detailed analysis of degradation rate curves (Fig. 6, right) showed that ash-wood, beech and pine fractions presented a global acceleration of solid mass loss interrupted by a brief deceleration at around $240{ }^{\circ} \mathrm{C}$, which is especially remarkable for pine $\mathrm{H}_{2}$ fraction. After that, these three fractions reached the maximum degradation rate at around $275{ }^{\circ} \mathrm{C}$. Wheat straw and miscanthus $\mathrm{H}_{2}$ fractions presented an acceleration of the mass loss until the maximum degradation rate, attained around $295{ }^{\circ} \mathrm{C}$. In both cases, the maximum of the degradation rate for each sample was attained at temperatures slightly higher than those for $\mathrm{H}_{1}$ fractions (Fig. 5, right). These maxima were followed by a deceleration of the solid mass loss which tended to stabilize in the isothermal stage.

To sum up, sugar composition strongly impacted hemicelluloses behavior in torrefaction, both in terms of extent of the degradation and remaining solid mass profile in function of time and temperature. Even if biomass type influenced sugar proportions in woody and agricultural biomasses (i.e. glucomannans in coniferous wood), it was shown to have a lower impact on hemicelluloses degradation than neutral monosugars composition.
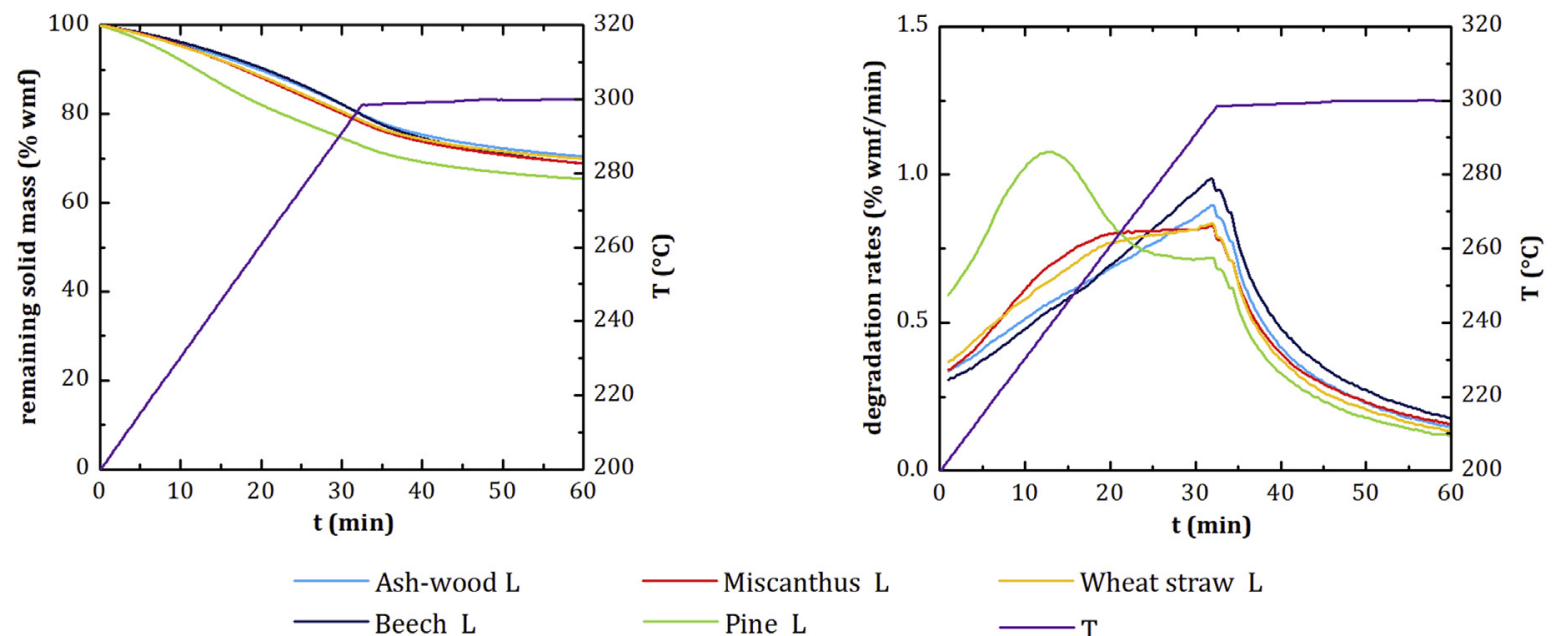

3.2.3. Lignin fraction $(L)$

The remaining solid mass at the end of the torrefaction experiment was few variable for all « lignin » extracted fractions (L), around 70.0 \%wmf, except for pine L fraction (65.1\%wmf, Fig. 7 , left). Degradation rates were low, below $1.1 \% \mathrm{wmf} \cdot \mathrm{min}^{-1}$, for all $\mathrm{L}$ fractions (Fig. 7, right). In this case, as L fractions could not be characterized in terms of $\mathrm{H}-, \mathrm{G}-$ and $\mathrm{S}$ - unit content, lignin composition as described in the literature will be considered $[13,25,68]$.

L fractions showed three solid kinetic patterns in the nonisothermal torrefaction step (0-33.3 min, Fig. 7, left), represented by the behaviors of deciduous wood L fractions (ash-wood and beech), agricultural by-products and herbaceous crops L fractions (wheat straw and miscanthus) and coniferous wood L fraction (pine). These patterns were confirmed by the degradation rates curves (Fig. 7, right). More precisely, ash-wood and beech L fractions presented a rather constant degradation rate acceleration until $300{ }^{\circ} \mathrm{C}$, with a slight change in the degradation rate curve around $250{ }^{\circ} \mathrm{C}$. This change was more pronounced for wheat straw and miscanthus L fractions, as their degradation rate was increasing from the beginning of the torrefaction until its stabilization around $250{ }^{\circ} \mathrm{C}$. Pine $\mathrm{L}$ degradation rate increased until around $235^{\circ} \mathrm{C}$ and 
then decreased, to finally stabilize from $275^{\circ} \mathrm{C}$. By considering the isothermal torrefaction step, all $\mathrm{L}$ fractions presented a progressive decrease of their degradation rate. The final low solid mass loss measured for all lignin fractions, as well as the low degradation rates observed, are in agreement with the partial degradation of lignin in the torrefaction temperature range reported in the literature $[8,17]$. Furthermore, the differences in lignin structure according to biomass type might explain these observations: G-type lignin (mostly in pine lignin) would seem to be more easily degraded than H-type lignin (all biomasses), itself more easily degraded than S-type lignin (deciduous wood, mainly). However, these differences in the degradation patterns might also be due to cleavage of internal bonds in lignin units.

\subsubsection{Evolution of the elemental composition of the extracted} fractions

The elemental composition of the solid was characterized before and after torrefaction for $\mathrm{C}^{\mathrm{II}}$ (Fig. 8A), DMSOr (Fig. 8B), $\mathrm{H}_{1}$ (Fig. 8C) and $\mathrm{L}$ (Fig. 8D) fractions.

Small changes in elemental composition were observed for $\mathrm{C}^{\mathrm{II}}$ (Fig. 8A), DMSOr (Fig. 8B) and L (Fig. 8D) fractions, except pine L fraction, which was richer in carbon. In these cases, a similar result was shown for each extracted fraction from different biomasses, represented by a low dispersion of the points in the ternary diagrams. This behavior was in agreement with the small differences observed in the remaining solid mass profiles of the corresponding extracted fractions (Figs. 3-7). On the contrary, the evolution of $\mathrm{H}_{1}$ fractions elemental composition was shown to be dependent on the nature of the hemicellulose fractions (Fig. 8C). Their transformation was very limited for wheat straw $\mathrm{H}_{1}$ and more pronounced for the woody samples. However, remaining solid mass profiles were not directly correlated to changes in elemental composition of $\mathrm{H}_{1}$ fractions. These results confirmed the influence of the sugar composition on hemicelluloses conversion through torrefaction.

The increase in carbon content in the torrefied $\mathrm{Cl}^{\mathrm{II}}$ fractions was between 22.3 and $29.2 \%$, while their oxygen content was reduced by $15.3-22.2 \%$. In the case of $\mathrm{H}_{1}$ fractions, the enrichment of the carbon content in the solid went from 10.5 to $50.1 \%$, in detriment to a decrease in the oxygen content from 6.2 to $42.4 \%$ and sensible changes in the hydrogen content. It is noteworthy that the wheat straw sample suffered a more pronounced decrease of its hydrogen

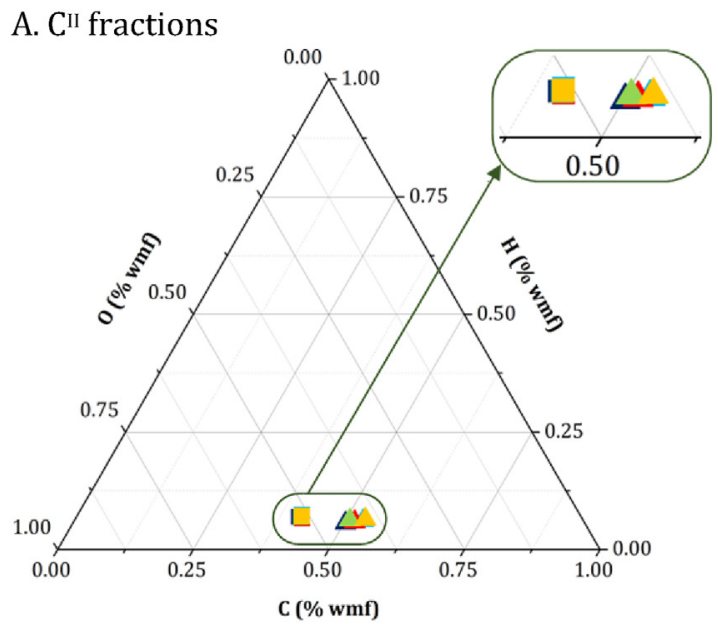

\section{B. DMSOr fractions}

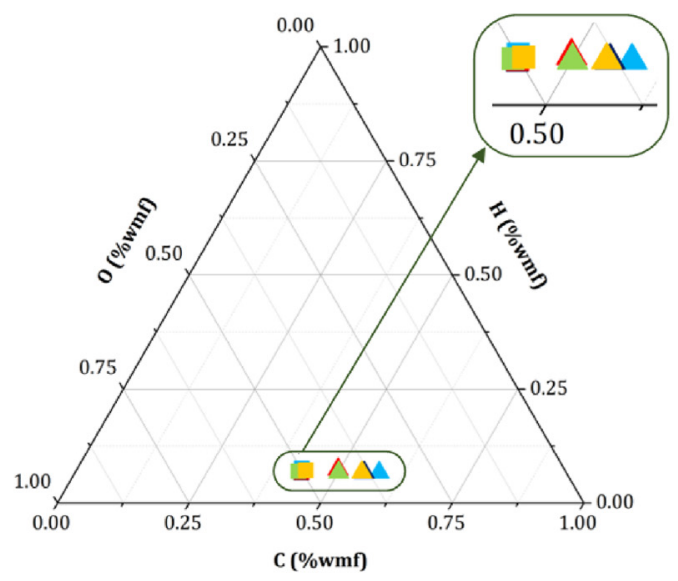

\section{C. $\mathrm{H}_{1}$ fractions}

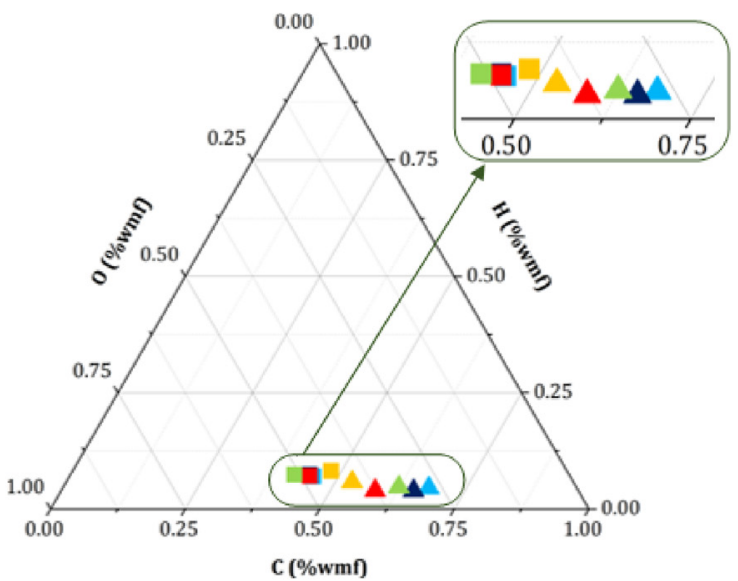

\section{L fractions}

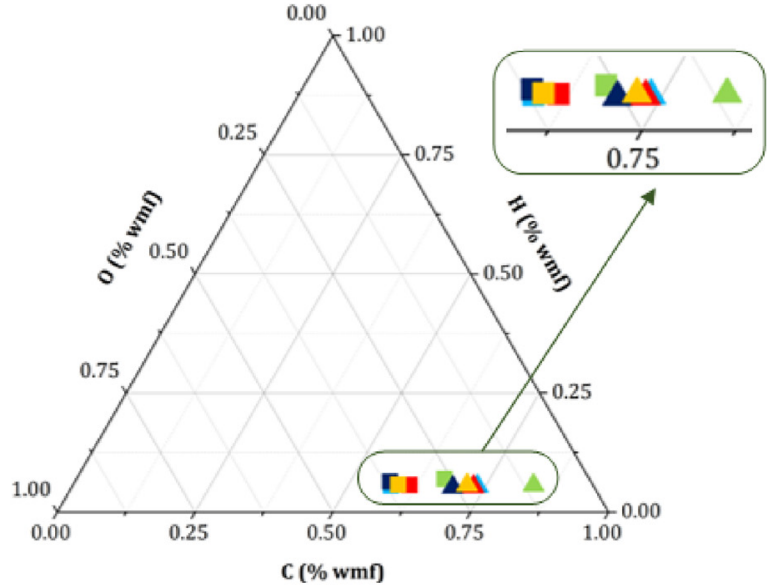

Ash-wood fraction (raw)

Beech fraction (raw)

Miscanthus fraction (raw)
Pine fraction (raw)

Wheat straw fraction (raw)

A Ash-wood fraction (torrefied)

A Pine fraction (torrefied)

- Beech fraction (torrefied)

- Miscanthus fraction (torrefied)

Fig. 8. Ternary diagram of CHO elemental composition of raw and torrefied $\mathrm{C}^{\mathrm{Il}}(8 \mathrm{~A})$, DMSOr (8B), $\mathrm{H}^{1}$ (8C) and $\mathrm{L}(8 \mathrm{D})$ fractions in TGA-GC/MS. 
content compared to its oxygen content, in proportion (28.7 and $6.2 \%$, respectively). The carbon content enrichment of the torrefied L fractions was between 19.2 and $27.3 \%$, comparable to that of $\mathrm{C}^{\mathrm{II}}$ fractions. This was associated with a decrease in oxygen from 29.6 to $59.1 \%$. This diminution might be explained by a high production of permanent gases and/or oxygenated phenolic compounds (not measured), according to previous studies in the literature [13].

These results enlighten the fact that the $\mathrm{C}, \mathrm{H}, \mathrm{O}$ elemental composition does not seem to be sufficient to differentiate the extracted fractions during torrefaction.

\section{Conclusions}

An optimized extraction procedure was proposed to obtain cellulose, hemicellulose and lignin fractions from five woody and agricultural biomasses. The torrefaction of the obtained extracted fractions showed different solid degradation profiles from those previously reported in the literature for commercial compounds. This result highlighted the importance of deeply characterizing the chemical compounds selected as representative for biomass modelling. Furthermore, biomass family (deciduous wood, coniferous wood, agricultural biomasses and herbaceous crops) may strongly impact the behavior of macromolecular components in torrefaction, especially for hemicelluloses and lignin.

The five $C^{\text {II }}$ fractions were few degraded in torrefaction. Their degradation started at lower temperatures (around $230{ }^{\circ} \mathrm{C}$ ) than those previously reported in the literature for commercial microcrystalline cellulose (around $300^{\circ} \mathrm{C}$ ). $\mathrm{C}^{\mathrm{II}}$ fractions presented a lower level of hemicellulose-sugars impurities than that reported for commercial cellulose. However, their allomorphic structure was different from that of the native cellulose in biomass. The comparison of the behavior of the DMSOr with that of the $\mathrm{C}^{\mathrm{II}}$ fractions in torrefaction may suggest a minor impact of cellulose allomorphic structure, while the presence of hemicellulose sugars enhance the degradation of a cellulose-based fraction, especially below $300{ }^{\circ} \mathrm{C}$.

The strong and fast degradation undergone by hemicelluloses in torrefaction was shown to be mainly conditioned by the sugar composition, especially by xylose and mannose. Furthermore, this degradation was different for the fractions extracted from the five biomasses of study. This behavior highlights the influence of the biomass type, which determines the proportions and the combination of sugars in hemicelluloses, on their degradation in torrefaction. As the behavior of $\mathrm{H}_{1}$ and $\mathrm{H}_{2}$ fractions for the same biomass was different due to their different sugar composition, both hemicellulose extracted fractions per biomass seem to be complementary to describe the global hemicellulose behavior in torrefaction.

L fractions degradation was shown to be very dependent on its composition in H- (phenyl-), G- (guaiacyl-) and S- (syringyl-) units. According to the results, three extracted lignin fractions would be enough to represent the lignin degradation pattern in biomass torrefaction, namely pine lignin (principally G- units), a deciduous wood lignin (G- and S-units) and an agricultural lignin (G-, S-, Hunits).

The evolution of the solid elemental composition through torrefaction, expressed by its major composition in carbon, oxygen and hydrogen, was only notable for $\mathrm{H}_{1}$ fractions. Lignin and cellulose present only moderate changes in their composition, due to their limited degradation at torrefaction temperatures. As a result, considering the main elemental composition instead of biomass macromolecular components seem to be insufficient, while biomass main macromolecular components would lead to a more accurate description of biomass behavior in torrefaction.

\section{CRediT authorship contribution statement}

María González Martínez: Conceptualization, Investigation, Formal analysis, Methodology, Visualization, Writing - original draft. Capucine Dupont: Conceptualization, Supervision, Project administration, Funding acquisition. Denilson da Silva Perez: Conceptualization, Methodology, Resources, Investigation. Gérard Mortha: Resources, Investigation. Sébastien Thiéry: Investigation. Xuân-mi Meyer: Methodology, Supervision, Validation. Christophe Gourdon: Methodology, Supervision, Validation.

\section{Declaration of competing interest}

The authors declare that they have no known competing financial interests or personal relationships that could have appeared to influence the work reported in this paper.

\section{Acknowledgments}

This project has received funding from the European Union's Horizon 2020 research and innovation program under grant agreement No 637020-MOBILE FLIP. The Université Fédérale de Toulouse Midi-Pyrénées (France), FCBA and Pagora-Grenoble INP (Grenoble, France) are also acknowledged for the support of this work.

\section{References}

[1] European Parliament, Council of the European Union. Directive (EU) 2018/ 2001 of the European Parliament and of the Council of 11 December 2018 on the promotion of the use of energy from renewable sources. http://data. europa.eu/eli/dir/2018/2001/oj. [Accessed 5 January 2020].

[2] Joint Research Centre (JRC). For the European commission's knowledge. Centre for Bioeconomy, Brief on biomass for energy in the European Union; 2019. https://doi.org/10.2760/546943.

[3] Chen W-H, Peng J, Bi XT. A state-of-the-art review of biomass torrefaction, densification and applications. Renew Sustain Energy Rev 2015;44:847-66 https://doi.org/10.1016/j.rser.2014.12.039.

[4] McKendry P. Energy production from biomass (part 1): overview of biomass Bioresour Technol 2002:37-46.

[5] Nhuchhen D, Basu P, Acharya B. A comprehensive review on biomass torrefaction. Int. J. Renew. Energy Biofuels. 2014:1-56. https://doi.org/10.5171/ 2014.506376.

[6] Bergman PCA, Boersma AR, Zwart RWR, Kiel JHA. Torrefaction for biomass cofiring in existing coal-fired power stations "BIOCOAL,". Energy research Centre of the Netherlands (ECN); 2015.

[7] Klinger J, Bar-Ziv E, Shonnard D. Kinetic study of aspen during torrefaction. J Anal Appl Pyrolysis 2013;104:146-52. https://doi.org/10.1016 j.jaap.2013.08.010

[8] Nocquet T, Dupont C, Commandre J-M, Grateau M, Thiery S, Salvador S. Volatile species release during torrefaction of wood and its macromolecular constituents: Part 1 - experimental study. Energy 2014;72:180-7. https:// doi.org/10.1016/j.energy.2014.02.061.

[9] Chen W-H, Wang C-W, Ong HC, Show PL, Hsieh T-H. Torrefaction, pyrolysis and two-stage thermodegradation of hemicellulose, cellulose and lignin. Fue 2019;258:116168. https://doi.org/10.1016/j.fuel.2019.116168.

[10] Patwardhan PR, Brown RC, Shanks BH. Product distribution from the fast pyrolysis of hemicellulose. ChemSusChem 2011;4:636-43. https://doi.org/ $10.1002 /$ cssc. 201000425.

[11] Wang S, Dai G, Ru B, Zhao Y, Wang X, Xiao G, Luo Z. Influence of torrefaction on the characteristics and pyrolysis behavior of cellulose. Energy 2017;120: 864-71. https://doi.org/10.1016/j.energy.2016.11.135.

[12] González Martínez M, Floquet P, Dupont C, da Silva Perez D, Meyer X. Assessing the impact of woody and agricultural biomass variability on its behaviour in torrefaction through Principal Component Analysis. Biomass Bioenergy 2020;134:105474. https://doi.org/10.1016 j.biombioe.2020.105474.

[13] Collard F-X, Blin J. A review on pyrolysis of biomass constituents: mechanisms and composition of the products obtained from the conversion of cellulose hemicelluloses and lignin. Renew Sustain Energy Rev 2014;38:594-608. https://doi.org/10.1016/j.rser.2014.06.013.

[14] Chen D, Gao A, Cen K, Zhang J, Cao X, Ma Z. Investigation of biomass torrefaction based on three major components: hemicellulose, cellulose, and lignin. Energy Convers Manag 2018;169:228-37. https://doi.org/10.1016/ j.enconman.2018.05.063.

[15] Prins MJ, Ptasinski KJ, Janssen FJJG. More efficient biomass gasification via 
torrefaction. Energy 2006;31:3458-70. https://doi.org/10.1016/ j.energy.2006.03.008.

[16] Arias B, Pevida C, Fermoso J, Plaza MG, Rubiera F, Pis JJ. Influence of torrefaction on the grindability and reactivity of woody biomass, Fuel Process Technol 2008;89:169-75. https://doi.org/10.1016/j.fuproc.2007.09.002.

[17] Chen W-H, Kuo P-C. Torrefaction and co-torrefaction characterization of hemicellulose, cellulose and lignin as well as torrefaction of some basic constituents in biomass. Energy 2011;36:803-11. https://doi.org/10.1016/ j.energy.2010.12.036.

[18] Nocquet T, Dupont C, Commandre J-M, Grateau M, Thiery S, Salvador S. Volatile species release during torrefaction of biomass and its macromolecula constituents: Part 2 - modeling study. Energy 2014;72:188-94. https:// doi.org/10.1016/j.energy.2014.05.023.

[19] Werner K, Pommer L, Broström M. Thermal decomposition of hemicelluloses. J Anal Appl Pyrolysis 2014;110:130-7. https://doi.org/10.1016/ j.jaap.2014.08.013.

[20] Branca C, Blasi CD, Mango C, Hrablay I. Products and kinetics of glucomannan pyrolysis. https://doi.org/10.1021/ie400155x; 2013.

[21] Wang S, Ru B, Lin H, Luo Z. Degradation mechanism of monosaccharides and xylan under pyrolytic conditions with theoretic modeling on the energy profiles. Bioresour Technol 2013;143:378-83. https://doi.org/10.1016/ j.biortech.2013.06.026.

[22] Krässig HA. Cellulose, structure, accessibility and reactivity. Gordon and Breach Publishers; 1993. https://onlinelibrary.wiley.com/doi/abs/10.1002/ pola.1994.080321221.

[23] Scheller HV, Ulvskov P, Hemicelluloses. Annu Rev Plant Biol 2010;61:263-89. https://doi.org/10.1146/annurev-arplant-042809-112315.

[24] Sun R, Sun XF, Tomkinson J. Hemicelluloses and their derivatives. In: Hemicellul. Sci technol; 2003. p. 2-22. https://doi.org/10.1021/bk-20040864.ch001.

[25] Monties B. Les polymères végetaux: les lignines. 1980.

[26] Biagini E, Barontini F, Tognotti L. Devolatilization of biomass fuels and biomass components studied by TG/FTIR technique. Ind Eng Chem Res 2006;45: 4486-93. https://doi.org/10.1021/ie0514049.

[27] Williams PT, Besler S. The influence of temperature and heating rate on the slow pyrolysis of biomass. Renew Energy 1996;7:233-50. https://doi.org 10.1016/0960-1481(96)00006-7.

[28] Prins MJ, Ptasinski KJ, Janssen FJJG. Torrefaction of wood. Part 2. Analysis of products. J Anal Appl Pyrolysis 2006;77:35-40. https://doi.org/10.1016/ j.jaap.2006.01.001.

[29] Prins MJ, Ptasinski KJ, Janssen FJJG. Torrefaction of wood: Part 1. Weight loss kinetics. J Anal Appl Pyrolysis 2006;77:28-34. https://doi.org/10.1016/ j.jaap.2006.01.002.

[30] Bates RB, Ghoniem AF. Biomass torrefaction: modeling of volatile and solid product evolution kinetics. Bioresour Technol 2012;124:460-9. https:|/ doi.org/10.1016/j.biortech.2012.07.018.

[31] Moya R, Rodríguez-Zúñiga A, Puente-Urbina A, Gaitán-Álvarez J. Study of light, middle and severe torrefaction and effects of extractives and chemical compositions on torrefaction process by thermogravimetric analysis in five fast-growing plantations of Costa Rica. Energy 2018;149:1-10. https:/ doi.org/10.1016/j.energy.2018.02.049.

[32] Lauberts M, Lauberte L, Arshanitsa A, Dizhbite T, Dobele G, Bikovens O, Telysheva G. Structural transformations of wood and cereal biomass components induced by microwave assisted torrefaction with emphasis on extractable value chemicals obtaining. J Anal Appl Pyrolysis 2018. https:| doi.org/10.1016/j.jaap.2018.03.025.

[33] Patwardhan PR, Satrio JA, Brown RC, Shanks BH. Influence of inorganic salts on the primary pyrolysis products of cellulose. Bioresour Technol 2010;101: 4646-55. https://doi.org/10.1016/j.biortech.2010.01.112.

[34] Kleen M, Gellerstedt G. Influence of inorganic species on the formation of polysaccharide and lignin degradation products in the analytical pyrolysis of pulps. J Anal Appl Pyrolysis 1995;35:15-41. https://doi.org/10.1016/01652370(95)00893-J.

[35] Dupont C, Jacob S, Marrakchy KO, Hognon C, Grateau M, Labalette F, Da Silva Perez D. How inorganic elements of biomass influence char steam gasification kinetics. Energy 2016;109:430-5. https://doi.org/10.1016 j.energy.2016.04.094.

[36] Romero Millán LM, Sierra Vargas FE, Nzihou A. Steam gasification behavior of tropical agrowaste: a new modeling approach based on the inorganic composition. Fuel 2019;235:45-53. https://doi.org/10.1016/ j.fuel.2018.07.053.

[37] Khazraie Shoulaifar T, DeMartini N, Karlström O, Hupa M. Impact of organically bonded potassium on torrefaction: Part 1. Experimental, Fuel 2016;165: 544-52. https://doi.org/10.1016/j.fuel.2015.06.024.

[38] de Macedo LA, Commandré J-M, Rousset P, Valette J, Pétrissans M. Influence of potassium carbonate addition on the condensable species released during wood torrefaction. Fuel Process Technol 2018;169:248-57. https://doi.org/ 10.1016/j.fuproc.2017.10.012

[39] Zhang S, Su Y, Ding K, Zhu S, Zhang H, Liu X, Xiong Y. Effect of inorganic species on torrefaction process and product properties of rice husk. Bioresour Technol 2018;265:450-5. https://doi.org/10.1016/j.biortech.2018.06.042.

[40] Safar M, Lin B-J, Chen W-H, Langauer D, Chang J-S, Raclavska H, Pétrissans A, Rousset P, Pétrissans M. Catalytic effects of potassium on biomass pyrolysis, combustion and torrefaction. Appl Energy 2019;235:346-55. https://doi.org/ 10.1016/j.apenergy.2018.10.065
[41] González Martínez M, Dupont C, Thiéry S, Meyer X-M, Gourdon C. Impact of biomass diversity on torrefaction: study of solid conversion and volatile species formation through an innovative TGA-GC/MS apparatus. Biomass Bioenergy 2018;119:43-53. https://doi.org/10.1016/j.biombioe.2018.09.002.

[42] Rubin EM. Genomics of cellulosic biofuels. Nature 2008;454:841-5. https:/ doi.org/10.1038/nature07190.

[43] Harris PJ. Primary and secondary plant cell walls: a comparative overview. N Z J For Sci 2006:36-53.

[44] Harrington J], Booker R, Astley RJ. Modelling the elastic properties of softwood. Part I: the cell-wall lamellae. Holz Als Roh- Werkst: 1998, p. 37-41.

[45] Stevanovic T. Chemical composition and properties of wood. In: Lignocellul. Fibers wood handb. Wiley-Blackwell; 2016. p. 49-106. https://doi.org/ 10.1002/9781118773727.ch3.

[46] Johar N, Ahmad I, Dufresne A. Extraction, preparation and characterization of cellulose fibres and nanocrystals from rice husk. Ind Crop Prod 2012;37:93-9. https://doi.org/10.1016/jindcrop.2011.12.016.

[47] Goda K, Sreekala MS, Gomes A, Kaji T, Ohgi J. Improvement of plant based natural fibers for toughening green composites-effect of load application during mercerization of ramie fibers. Composer Part Appl Sci Manuf 2006;37: 2213-20. https://doi.org/10.1016/j.compositesa.2005.12.014.

[48] Oudiani AE, Chaabouni Y, Msahli S, Sakli F. Crystal transition from cellulose I to cellulose II in $\mathrm{NaOH}$ treated Agave americana L. fibre, Carbohydr. Polymer 2011;86:1221-9. https://doi.org/10.1016/j.carbpol.2011.06.037.

[49] Hägglund E, Lindberg B, McPherson J. Dimethylsulphoxide, a solvent for hemicelluloses. Acta Chem Scand 1956;10:1160-4. https://doi.org/10.3891/ acta.chem.scand.10-1160.

[50] Rowley J, Decker SR, Michener W, Black S. Efficient extraction of xylan from delignified corn stover using dimethyl sulfoxide. 3 Biotech 2013;3:433-8. https://doi.org/10.1007/s13205-013-0159-8.

[51] Ebringerová A, Hromádková Z, Heinze T. Hemicellulose. In: Heinze T, editor. Polysacch. I. Springer Berlin Heidelberg; 2005. p. 1-67. https://doi.org/ $10.1007 / \mathrm{b} 136816$.

[52] Ebringerová A, Heinze T. Xylan and xylan derivatives - biopolymers with valuable properties, 1 . Naturally occurring xylans structures, isolation procedures and properties. Macromol Rapid Commun 2000;21:542-56. https:// doi.org/10.1002/1521-3927(20000601)21:9<542::AID-MARC542>3.0.CO;2-7.

[53] Tribot A, Amer G, Abdou Alio M, de Baynast H, Delattre C, Pons A, Mathias J-D, Callois J-M, Vial C, Michaud P, Dussap C-G. Wood-lignin: supply, extraction processes and use as bio-based material. Eur Polym J 2019;112:228-40. https://doi.org/10.1016/j.eurpolymj.2019.01.007.

[54] Carvajal JC, Gómez Á, Cardona CA. Comparison of lignin extraction processes: economic and environmental assessment, Bioresour. Technol 2016;214: 468-76. https://doi.org/10.1016/j.biortech.2016.04.103.

[55] Gellerstedt G, Pranda J, Lindfors E-L. Structural and molecular properties of residual birch kraft lignins. J Wood Chem Technol 1994;14:467-82. https:/ doi.org/10.1080/02773819408003108.

[56] Guerra A, Lucia LA, Argyropoulos DS. Isolation and characterization of lignins from Eucalyptus grandis Hill ex Maiden and Eucalyptus globulus Labill. by enzymatic mild acidolysis (EMAL). Holzforschung 2008;62:24-30. https:// doi.org/10.1515/HF.2008.004.

[57] Fahmi R, Bridgwater AV, Thain SC, Donnison IS, Morris PM, Yates N. Prediction of Klason lignin and lignin thermal degradation products by Py-GC/MS in a collection of Lolium and Festuca grasses. J Anal Appl Pyrolysis 2007;80:16-23. https://doi.org/10.1016/j.jaap.2006.12.018.

[58] da Silva Perez D, Dupont C, Guillemain A, Jacob S, Labalette F, Briand S, Marsac S, Guerrini O, Broust F, Commandre J-M. Characterisation of the most representative agricultural and forestry biomasses in France for gasification. Waste Biomass Valorization 2015;6:515-26. https://doi.org/10.1007/s12649015-9374-3.

[59] Ahlgren PA, Goring DaI. Removal of wood components during chlorite delignification of black spruce. Can J Chem 1971;49:1272-5. https://doi.org/ $10.1139 / v 71-207$.

[60] Rodriguez Alonso E. Contribution to the study of formation mechanisms of condensable by-products from torrefaction of various biomasses. Toulouse: INPT; 2015. http://www.theses.fr/2015INPT0148. [Accessed 27 February 2018]

[61] González Martínez M, Dupont C, Thiery S, Meyer XM, Gourdon C. Characteristic time analysis of biomass torrefaction phenomena - application to thermogravimetric analysis device. Chem. Eng. Trans. 2016;50:61-6. https:// doi.org/10.3303/CET1650011.

[62] Nocquet T. Torréfaction du bois et de ses constituants: expériences et modélisation des rendements en matières volatiles. Université de Toulouse; 2012. http://ethesis.inp-toulouse.fr/archive/00002140/01/nocquet.pdf.

[63] González Martínez M, Ohra-aho T, da Silva Perez D, Tamminen T, Dupont C. Influence of step duration in fractionated Py-GC/MS of lignocellulosic biomass. J Anal Appl Pyrolysis 2019;137:195-202. https://doi.org/10.1016/ j.jaap.2018.11.026.

[64] Chauve M. Modélisation cinétique de l'hydrolyse enzymatique des substrats cellulosiques. Influence de la structure et morphologie du substrat, phdthesis. Université de Grenoble; 2011. https://tel.archives-ouvertes.fr/tel-00680091/ document. [Accessed 6 September 2018].

[65] Kolpak FJ, Blackwell J. Determination of the structure of cellulose II. Macromolecules 1976;9:273-8. https://doi.org/10.1021/ma60050a019.

[66] Lédé J. Cellulose pyrolysis kinetics: an historical review on the existence and role of intermediate active cellulose. J Anal Appl Pyrolysis 2012;94:17-32. 
https://doi.org/10.1016/j.jaap.2011.12.019.

[67] Stefanidis SD, Kalogiannis KG, Iliopoulou EF, Michailof CM, Pilavachi PA Lappas AA. A study of lignocellulosic biomass pyrolysis via the pyrolysis of cellulose, hemicellulose and lignin. J Anal Appl Pyrolysis 2014;105:143-50. https://doi.org/10.1016/j.jaap.2013.10.013.
[68] del Río JC, Gutiérrez A, Rodríguez IM, Ibarra D, Martínez ÁT. Composition of non-woody plant lignins and cinnamic acids by Py-GC/MS, Py/TMAH and FTIR. J Anal Appl Pyrolysis 2007;79:39-46. https://doi.org/10.1016/ j.jaap.2006.09.003. 